E.hasanvand@mnc.put.ac.ir إنشجوى كارشناسى ارشد، مهندسى سازهاى دريايى، دانشخاه صنعت نفت، آبادان، ايران،

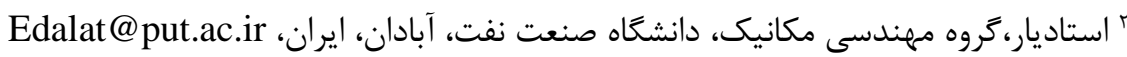

\begin{tabular}{|c|}
\hline 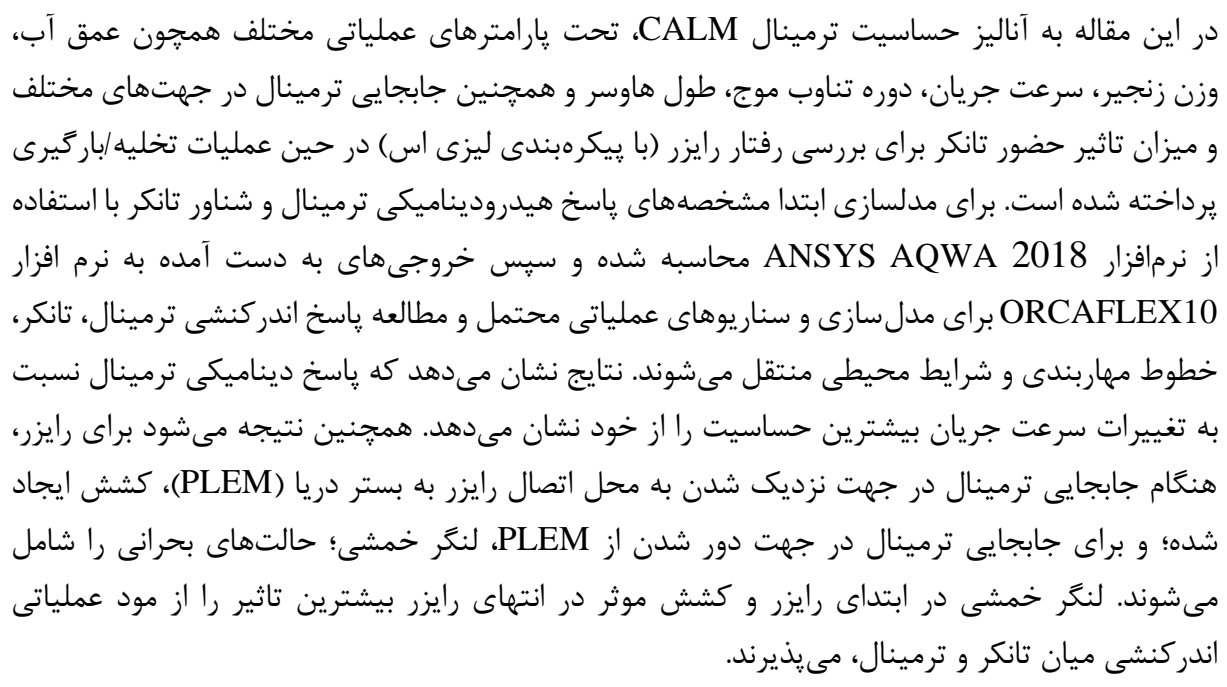 \\
\hline
\end{tabular}

اطلاعات مقاله

تاريخجه مقاله:

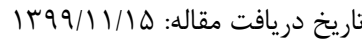

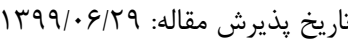

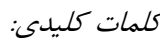

آناليز حساسيت

ترمينال نفتى فراساحل

CALM

ياسخ ديناميكى

تحليل مهاربندى ديناميكى

\title{
Sensitivity Analysis of the Dynamic Response of CALM Oil Terminal, in The Persian Gulf Region Under Different Operation Parameters
}

\author{
Esmaeil Hasanvand ${ }^{1}$, Pedram Edalat ${ }^{2 *}$ \\ ${ }^{1}$ M.Sc. Offshore Structure Engineering Department, Petroleum University of Technology, Abadan, Iran; \\ E.hasanvand@mnc.put.ac.ir \\ ${ }^{2}$ Assistant Professor, Mechanical Engineering Department, Petroleum University of Technology, Abadan; Edalat@put.ac.ir
}

\section{ARTICLE INFO}

Article History:

Received: 04 Feb. 2020

Accepted: 19 Sep. 2020

\section{Keywords:}

Sensitivity Analysis

Offshore oil terminal

CALM

Dynamic response

Mooring analysis

\begin{abstract}
This paper analyzes CALM terminal sensitivity under various operating parameters such as water depth, chain mass, current velocity, wave period, hawser length as well as terminal displacement in different directions, and the impact of tanker presence on the behavior of the riser (lazy S) during unloading/loading operations. The hydrodynamic response characteristics of the tanker and CALM buoy are calculated using ANSYS-AQWA software and the outputs are imported in OracleFlex software for simulation of the probable operating scenarios considering the terminal, tanker, mooring lines and Environmental conditions. The results indicate that the terminal dynamic response is most sensitive to the current velocity changes. It is also concluded that for the riser, when Near offset, an effective tension and for far offset, the bending moment includes critical states. The bending moment at the hang-off the riser and the effective tension at PLEM receive the most impact from the interactive mode of operation between the tanker and the terminal.
\end{abstract}


اولين مدل از سـازه CALM در ســال 1909 مورد اســفاده قرار

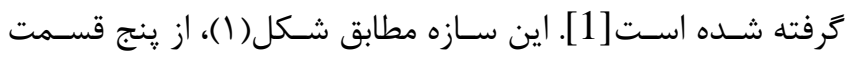

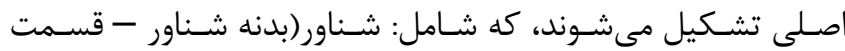

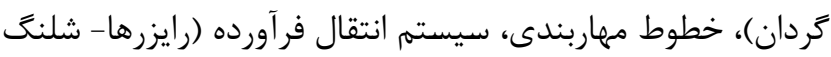
شـناور)، سيستم اتصال تانكر به ترمينال شـناور (هاوسر) و تجهيزات

موجود در بستر دريا (خطوط لوله دريايى - PLEM ) است.

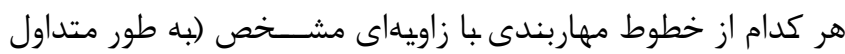

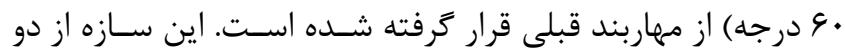
قسمت شامل قسمت كردان بالا و قسمت ثابت يايين تشكيل شده

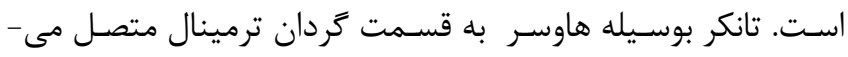

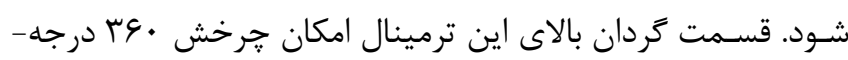

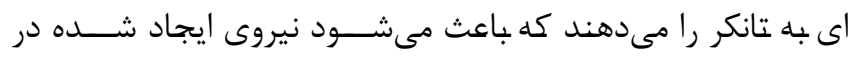

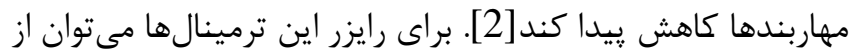

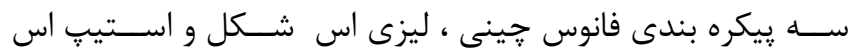

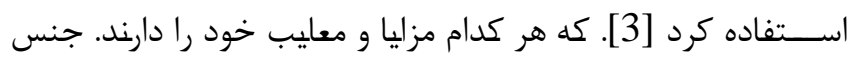

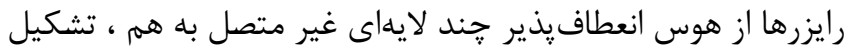
مىشـود. ترمينال نفتى CALM از دو قسـمت اصلى (بالا و رايين)

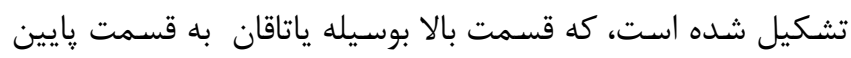
متصل است و تانكر بوسيله هاوسر به اين قسـمت متصل مىشـود.

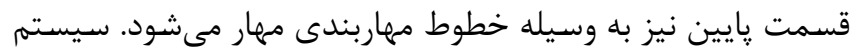

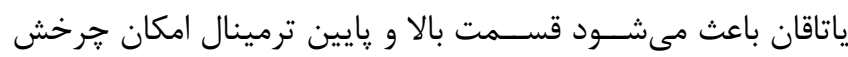

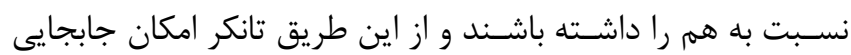

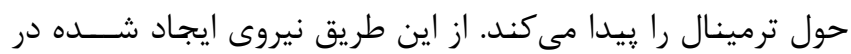
مهاربند كاهش مى يابد [2].

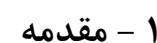
صادرات فراوردههاى نفتى از دو طريق خطوط لوله انتقال تا بايانه

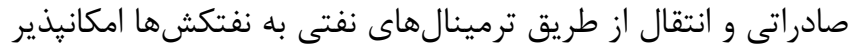
است. ترمينالهاى نفتى در دو نوع ساحلى و فراساحلى از جمله

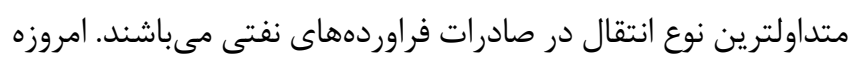
با توجه به هزينههاى قابل توجه احداث و نكَهداشت پإيانههاى

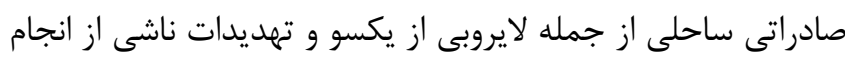

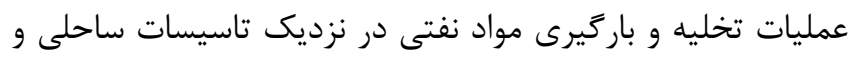

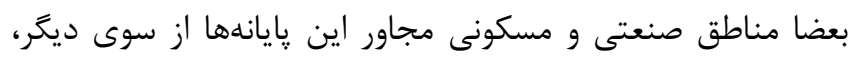

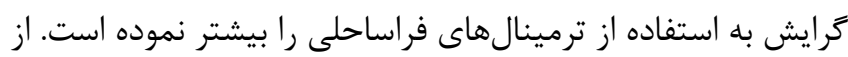

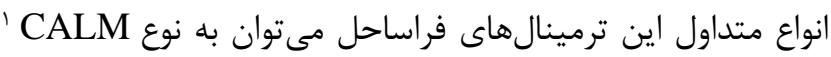

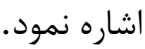

از مهمترين قسمتهاى موثر بر پاسخ ديناميكى ترمينال نفتى CALM

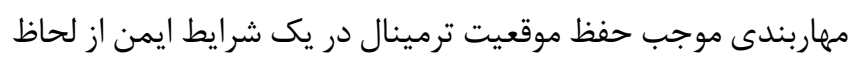
جابجايى براى عمليات باركيرى تانكر مىشود. در نتيجه طراحى اين

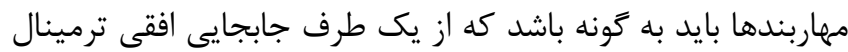
را در يك محدوده مجاز كنترل نمايد و از طرف ديكر كششهائ

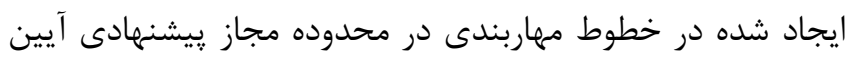

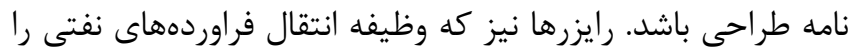

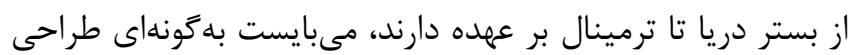

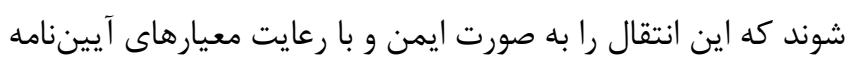
اى فراهم آورند. بنابراين شناخت يارامترهاى موثر و بررسى شدت إئات

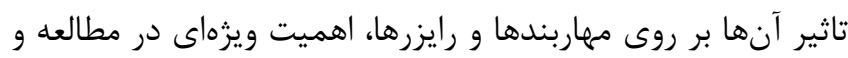
طراحى ترمينال هاى فراساحل دارند.

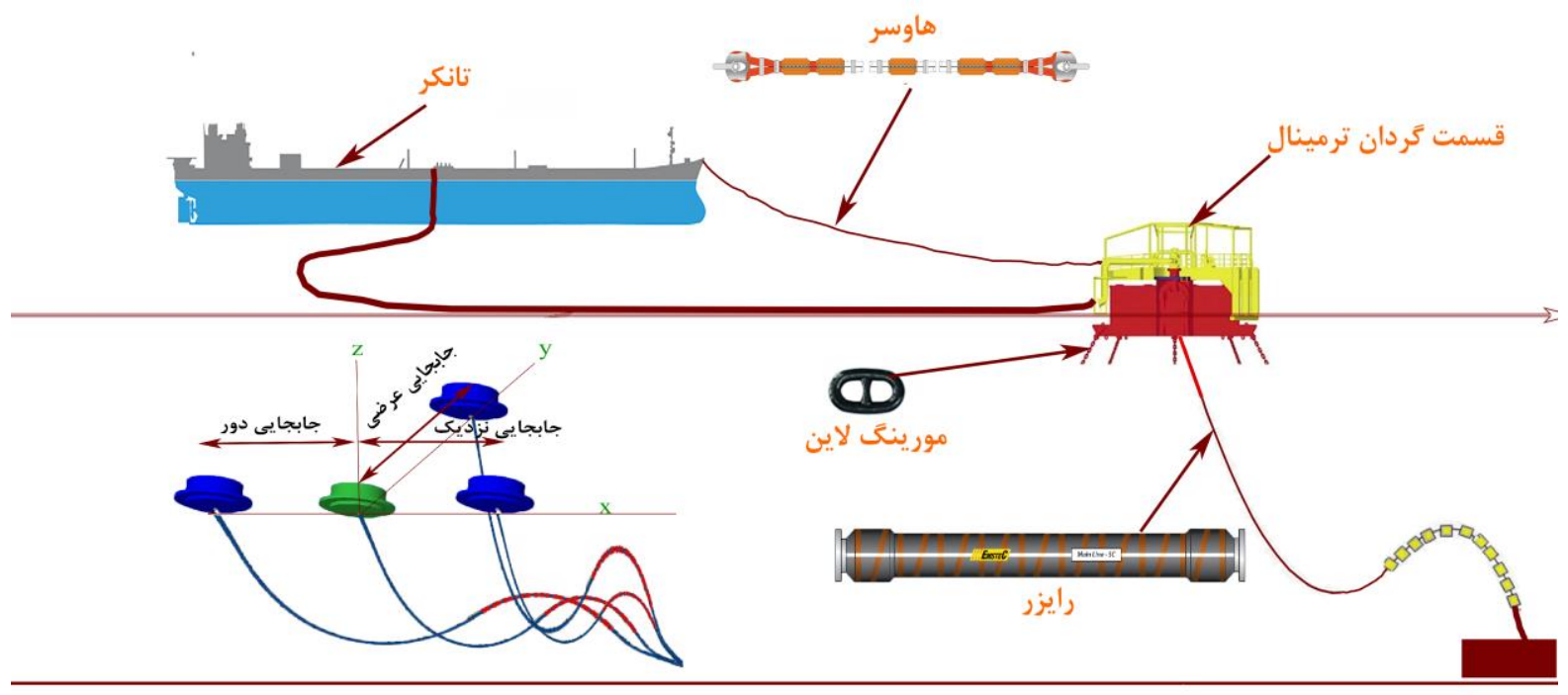

شكل ا ـ نماى شماتيكى از ترمينال نفتى CALM 
هوانگ در سال 199 رفتار ديناميكى سازه CALM را تحت بار

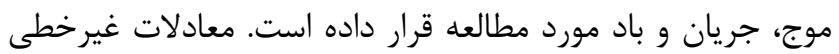
خطوط مهاربندى با استفاده از عناصر كابل فرموله شده بر اساس

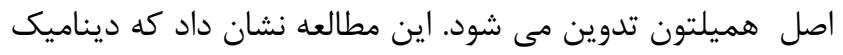
خطوط مهاربندى تاثير زيادى روى كشش ايجاد شده در اين خطوط إين

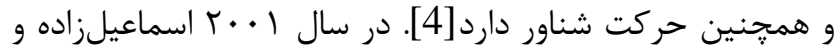
كودرززاده به بررسى پايدارى سازه CALM بدون اتصال به تانكر

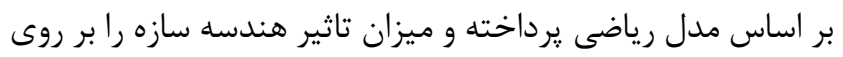

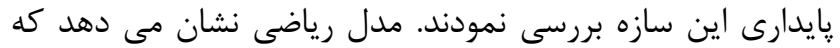
معادله حاكم بر حركت براى سيستم يك معادله ديفرانسيل درجه

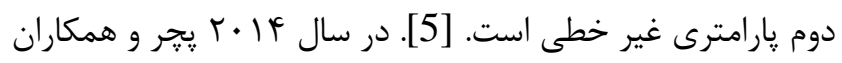

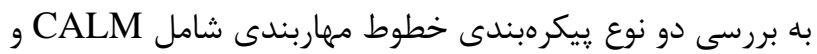
SALM ${ }^{r}$ بر اساس روابط موجود براى سيستم مهاربندى يرداخته و تاثيرى

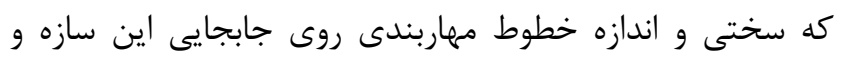

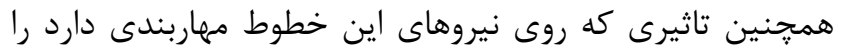

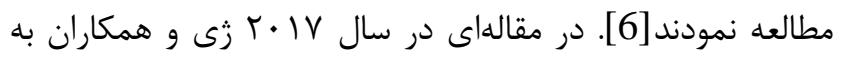

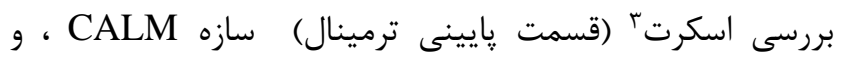

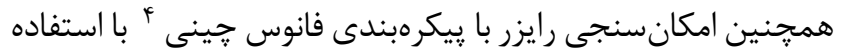

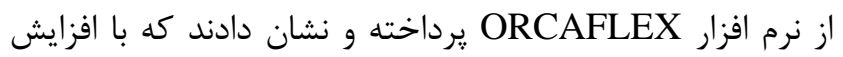

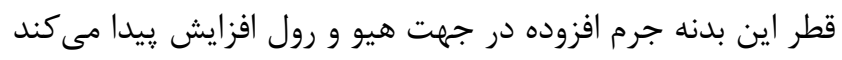

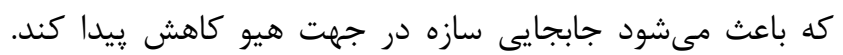
همجنين امكانيذير بودن استفاده از اين نوع پِيكرهبندى رايزر براى

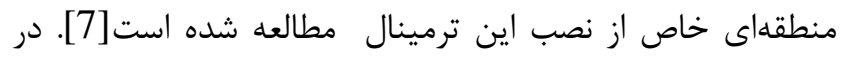

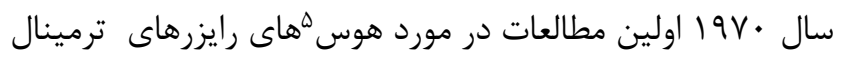

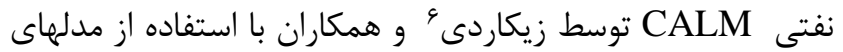

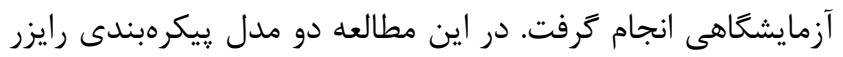

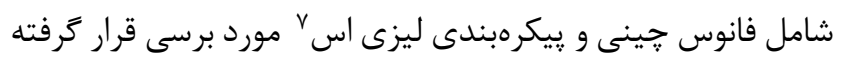

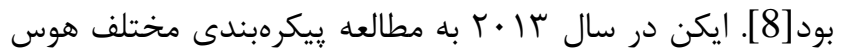

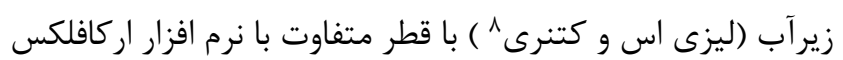

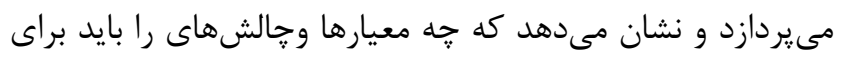

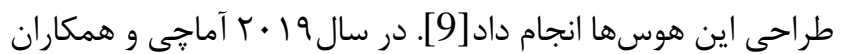
مقاومت رايزر CALM با پيكرهبندى فانوس جينى متصل به تانكر

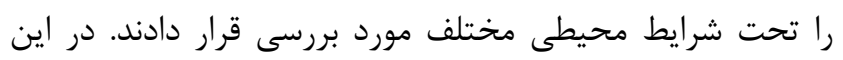

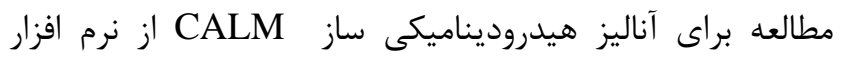
ORCAFLEX و براى آناليز رايزر از نرم افزار سارئار كمك كرفته شده است. هدف از اين مطالعه تعيين تاثير پارارامتر

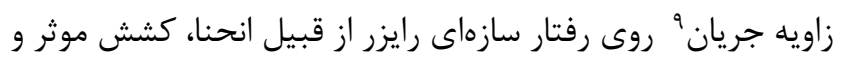

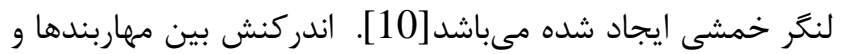

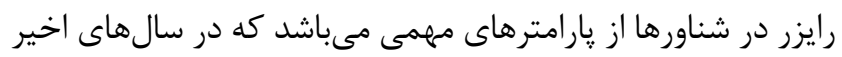
مطالعات فراوانى در اين خصوص انجام شده است [13:-111]
خطوط مهاربندى كه به عنوان سيستم نكَهدارنده موقعيت اين دسته

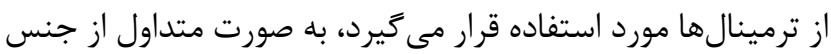

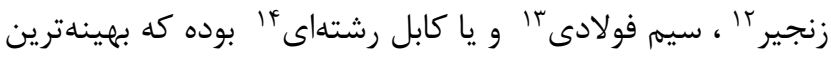

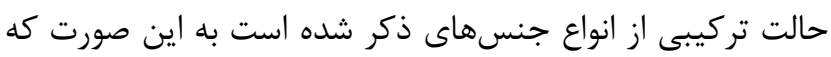

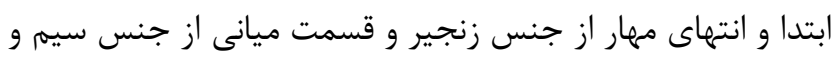

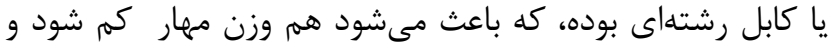
هم نيروى قائم وارد بر سازه كاهش يابد. به طور متداول مهاربند باديا

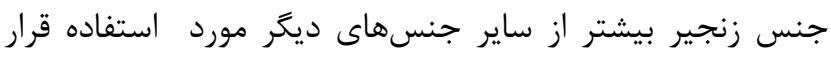

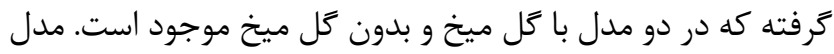

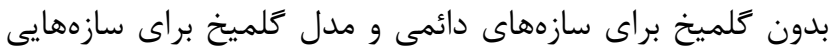

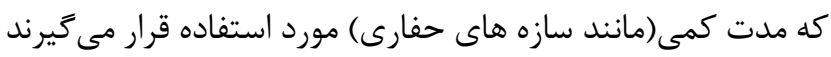

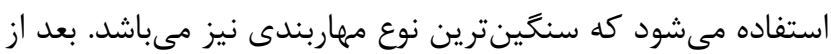

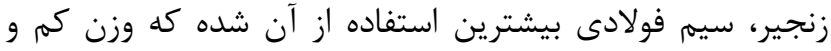

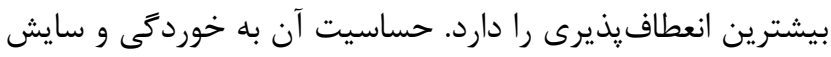

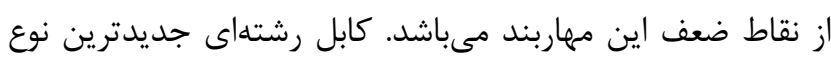
مورينگ بوده كه داراى انعطافيذيرى و مقاومت شكست كمترى

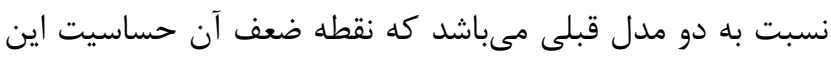

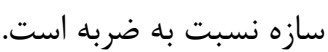
رايزرها براى انتقال فراوردههاى نفتى از بستر دريا تا قسمت بإيينى

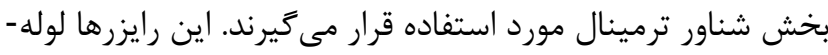

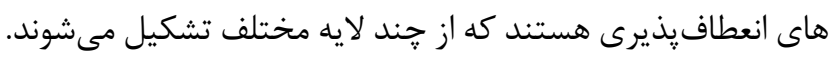
به رايزرهاى مورد استفاده در ترمينالهاى نفتى، اصطلاحاً هوسهاى آنسي زير آبها كفته مىشود. لايهها در اين هوسها بوسيله فرايند

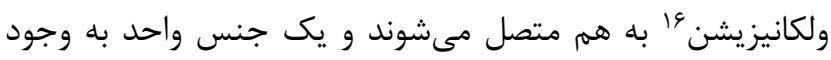

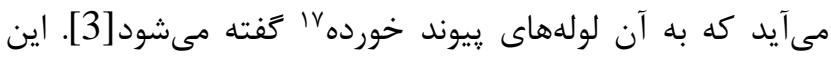
دسته از رايزرها معمولا به شكل سه بِ بيكرهبندى شامل فانوس جينى،

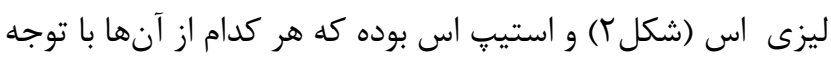
ملاحظات فنى و اقتصادى مورد نظر يروزه استفاده مىشوند.

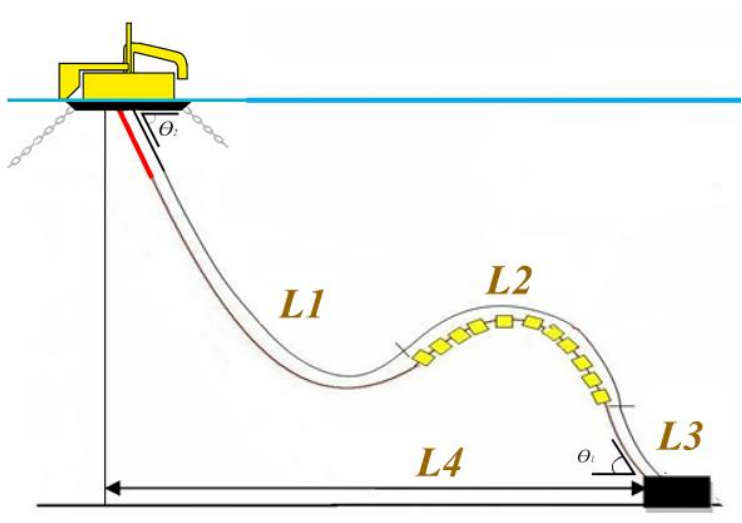

شكل r. بيكره بندى ليزى اس

در يك دستابندى كلى مطالعات و تحقيقات انجام شده در اين حوزه به دو بخش خطوط مهاربندى و سيستم رايزر تقسيم مىشوند. 
مهاربند در نقطه اتصال بالايى و Z2 ارتفاع قائم نقطه اتصال مهاربند

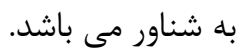

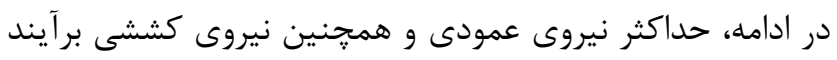
در نقطه اتصال روى شناور طبق روابط (זو س) مىتواند محاسبه شود. $V_{2}=W L$

$T_{2}=\sqrt{H_{2}^{2}+V_{2}^{2}}$

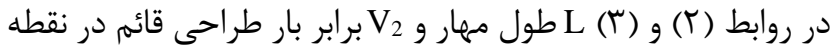

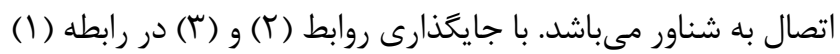

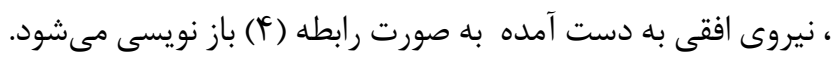

$$
H_{2}=\frac{V_{2}^{2}-\left(W Z_{2}-\frac{W^{2} \times L^{2}}{2 \times A E}\right)^{2}}{2\left(W Z_{2}-\frac{W^{2} \times L^{2}}{2 \times A E}\right)}
$$

همجنين طول فاصله افقى بين نقطه ابتدا و انتهاى مهار X2 را مى توان طبق رابطه (ه) به دست آورد.

$$
X_{2}=\frac{H_{2}}{W} \sinh ^{-1}\left(\frac{w L}{H_{2}}\right)+\frac{H_{2} L}{A E}
$$

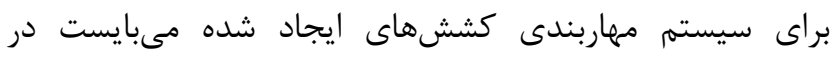

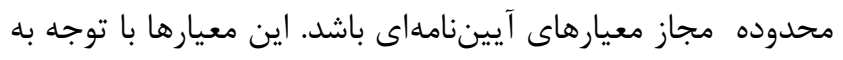

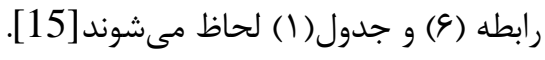

$$
\text { حداكثر كشش ايجاد شده مهاربند مجاز }
$$

\begin{tabular}{|c|c|}
\hline $1.9 \mathrm{~V}$ & در حالت مههاربندى سالم \\
\hline $1 . r \Delta$ & در حالت با يك مههاربند آس \\
\hline
\end{tabular}

\section{جدول ا. ضرايب ايمنى ارائه شده در آيين نامه API-RP-2SK}

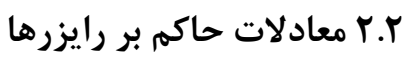

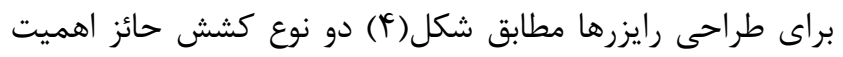

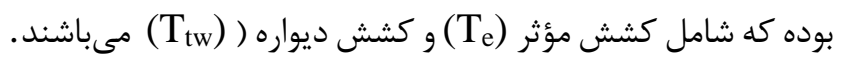

با توجه به مطالعات كذشته، تاكنون ياسخ ترمينال شناور تحت تاثير

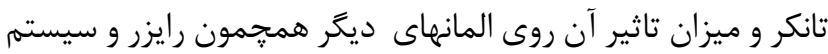
مهاربندى انجام نكرفته است. كابل اتصال بين تانكر و ترمينال نيز

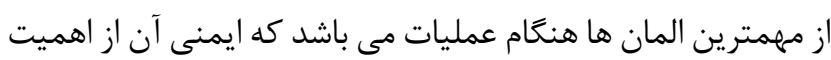

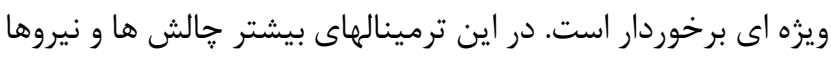

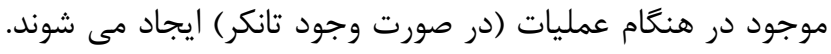

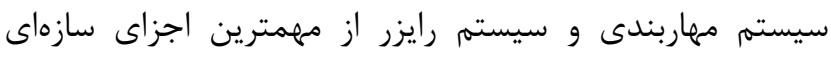

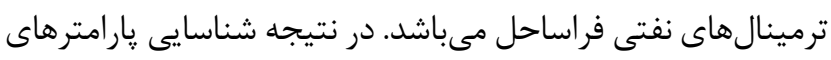
تاثير كذار بر روى اين اجزاى سازهاى در فرآيند طراحى بسيار حائز

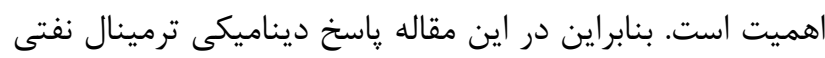

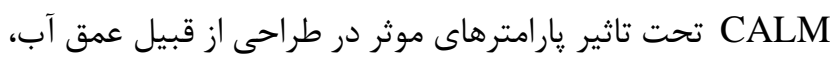

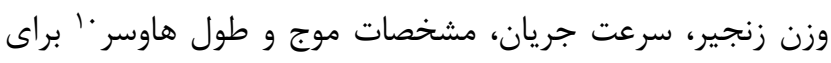

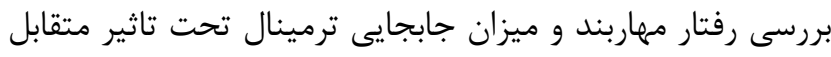

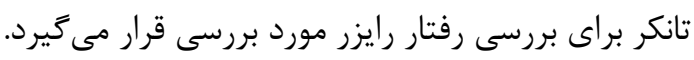

r. معادلات حاكم بر مسئله

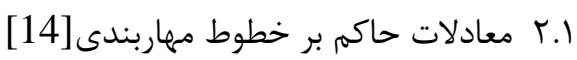

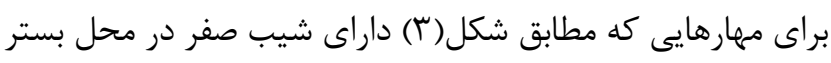

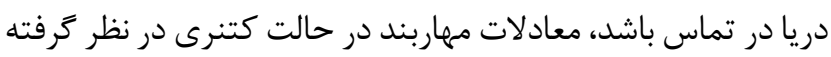
مىشود كه در ادامه به بيان اين روابط يرداخته خواهد شد.

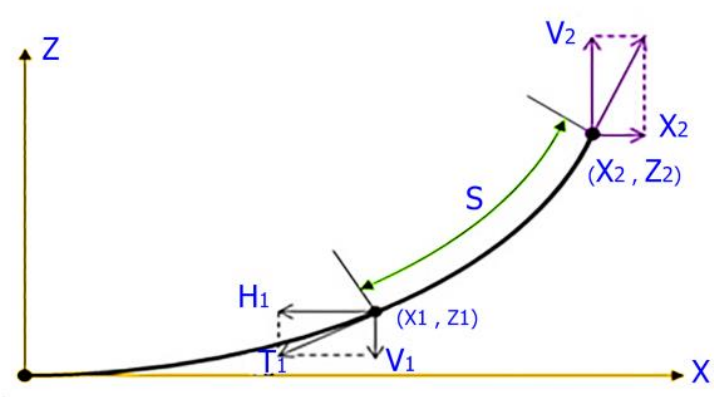

شكل r. يارامتر هاى موجود در مهاربند در حالت كتنرى

نيروهاى موجود در نقاط مختلف و تحت تنشهاى مختلف، با در

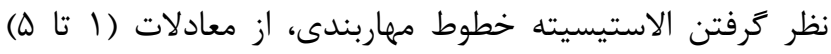

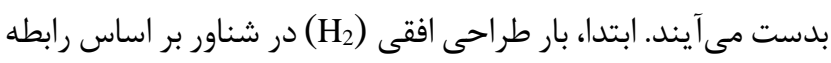
(1) و با توجه به ساير مشخصات سيستم محاسبه مىشود.

$$
H_{2}=A E \sqrt{\left(\frac{T_{2}}{A E}+1\right)^{2}-\frac{2 W Z_{2}}{A E}}-A=H
$$

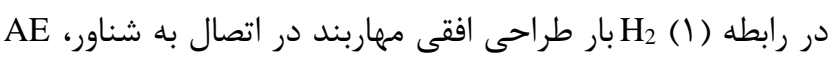

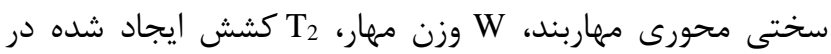


r. (- مطالعه موردى

با هدف بررســى تاثير يارامترهاى مختلف همجون عمق آب، وزن مورى زنجير، شـــدت جريـان و يريود موج بر رفتار مهاربند و همجنين

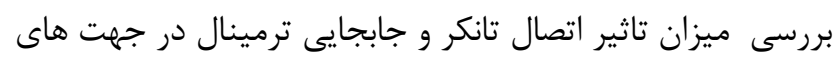
مختلف روى ياسـخ رايزر، به مدلسـازى و تحليل سـازهاى اين نوع

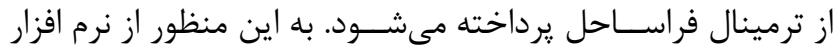

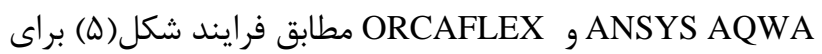
مدلســازى عددى اســتفاده شــده اسـت[10]. ابتدا در نرم افزار ANSYS AQWA

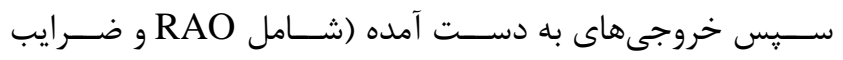

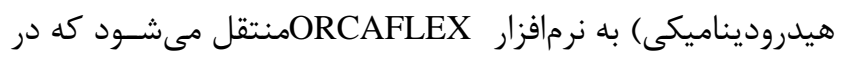
آن مشخصات مهاربندها، رايزرها و همجنين مشخصات محريطى و ورهار

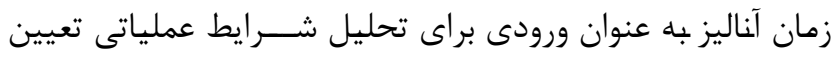

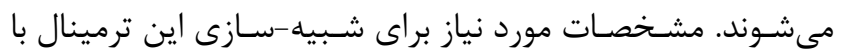

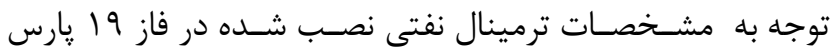
جنوبى انجام مى گيرد كه در ادامه به آنها اشاره مىشود.

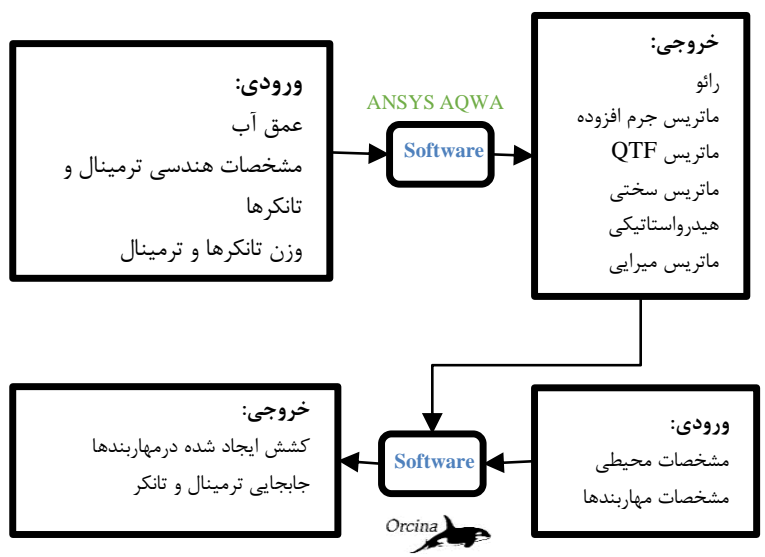

شكل ه. فرايند مدل سازى در ترمينال نفتى CALM در نرم افزار

مشخصات هندسى تانكر و ترمينال در جدول( (1) آورده شده است. همانطور كه ييشتر نيز اشاره شد يكى از خصوصيتهاى عملياتى

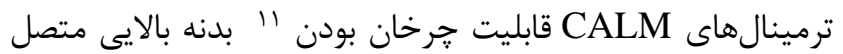
به تانكر بوده كه براى شبيهسازى ايجاد جرخش دو قسمت بالا و

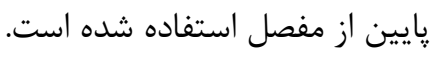

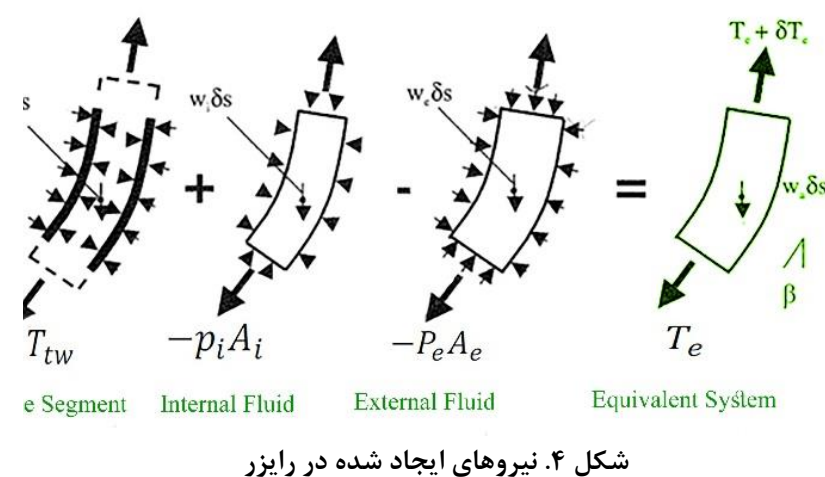

كشش مؤثر (Te) و كشش ديواره(T) ارتباط هستند. [6] كؤن

$T_{e}=T_{t w}+\left(-P_{i} A_{i}\right)+\left(-P_{e} A_{e}\right)$

در رابطه بالا Pi فشار خار داخلى لوله كه در سطح آب صفر و مقدار آن با كاهش عمق افزايش بيدا مى كند. همجنين - سطح مقطع داخلى و خارجى ناحيه تنش محيطى مئى $A_{i}$

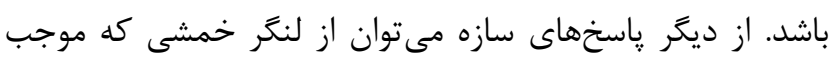

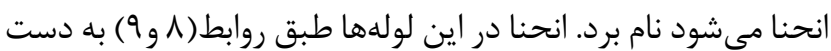

$$
\begin{aligned}
& k=\frac{w_{a}}{T_{h}} \cos h \frac{x w_{a}}{T_{h}} \\
& W_{a}=W_{h}+W_{i}-W_{e}
\end{aligned}
$$

در رابطه بالا X ، فاصله افقى دو نقطه ابتدا و انتهاى رايزر، Th نيروى

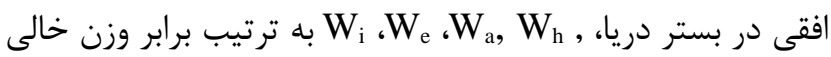
لوله، وزن ظاهرى, وزن خارجى اطراف لوله و وزن سيال داخل لوله است. همجنين شعاع خمشى برابر معكوس انحنا مىباشد. لنگر خمشى مجاز و انحناى مجاز بر اساس حداقل شعاع خمش 19 هر لوله رايزر كه توسط شركت سازنده مشخص مىشود، به دست مى -

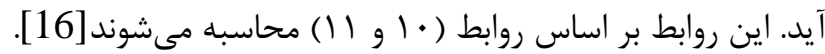

$$
\begin{aligned}
& \text { ل }=\frac{E I}{M B R} \\
& \text { خمشى }=\frac{1}{M B R}
\end{aligned}
$$

در روابط بالا EI سختى خمشى لوله MBR حداقل انحناى مجاز مىباشد كه جزء مشخصههاى رايزرها بوده كه توسط شركت سازنده مشخص مى مئرد. 
جدول r. مشخصات مكانيكى رايزر

\begin{tabular}{|c|c|}
\hline مقدار & 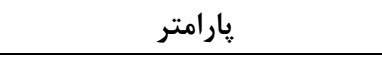 \\
\hline $1 \cdot . V$ & طول هر بخش رايزر \\
\hline$\Delta \cdot \cdot$ & قطر داخلى [mm] \\
\hline 9r. & قطر خارجى [mm] \\
\hline 101 & سختى خمشى [kN.m² \\
\hline FrTQ.A99 & سختى محورى [kN] \\
\hline$r \Delta q$ & جرم در آب] \\
\hline 11. & حداقل كشش شكست 18 ] \\
\hline VTS & 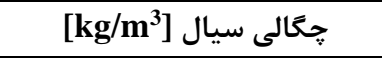 \\
\hline vr & طول \\
\hline$r \wedge .9$ & طول \\
\hline $11+.1$ & طول] L3] [m] \\
\hline 11 & طول [m] [m] \\
\hline 111 & طول كل رايزر L] L \\
\hline
\end{tabular}

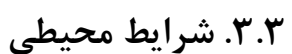

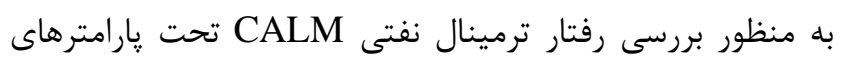

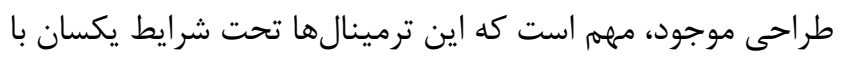

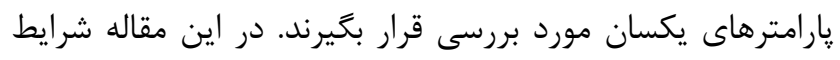

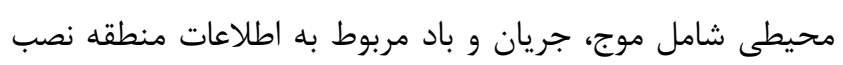

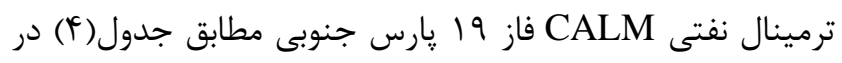

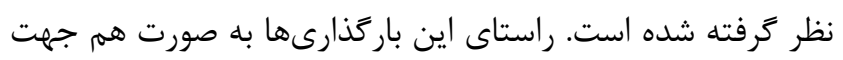

جدول F. مشخصات خطوط مهاربندى

\begin{tabular}{|c|c|c|}
\hline مقادير & & يارامتر ها \\
\hline$\cdot .4 \cdot 9$ & هاوسر & \multirow{2}{*}{ قطر مهار] } \\
\hline 90 & خط مهار CALM & \\
\hline rrs & خط مهار CALM & \multirow{2}{*}{ طول زنجير[m] } \\
\hline Fr.A & هاوسر & \\
\hline 11. & \multicolumn{2}{|c|}{ جرم در آب] } \\
\hline$V V \cdot V r \Delta$ & \multicolumn{2}{|c|}{ سختى محورى [kN] EA] } \\
\hline$\Delta \wedge \wedge \mu$ & \multicolumn{2}{|c|}{ حداكثر كشش مجاز[kN] } \\
\hline
\end{tabular}

با خطوط مهاربند مطابق شكل(V) انجام مى مئيرد. براى بررسى رفتار

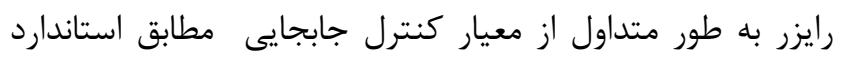
API

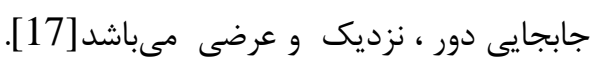

جدول r. مشخصات تانكر و ترمينال

\begin{tabular}{|c|c|c|}
\hline CALM & تانكر & I $\quad \because 1$ \\
\hline \multicolumn{2}{|c|}{ مقادير } & 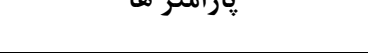 \\
\hline r.T99 & $\wedge$ & آبخور [m] \\
\hline - & 4. & مركز جرم در جهت .M] \\
\hline$\cdot$ & . & مركز جرم در جهت [m].Y \\
\hline$\cdot . v 99$ & $\Lambda . \Delta$ & مركز جرم در جهتZ] \\
\hline rAf.... & |AF. 99 & 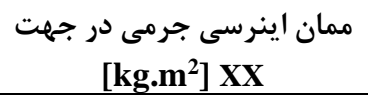 \\
\hline rAf.... & ra.. & 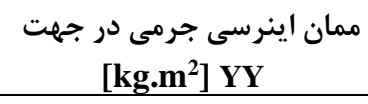 \\
\hline 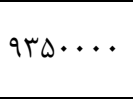 & $r V \cdot r$ & 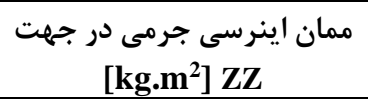 \\
\hline $1 \% .0$ & - & قطر] \\
\hline 19.94 & - & قطر اسكرت[m] \\
\hline$r \wedge 9.91$ & $r a \cdots$ & وزن[ton] \\
\hline$\Delta . r$ & - & [m] ارتفاع شناور \\
\hline
\end{tabular}

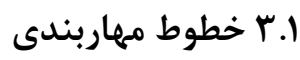

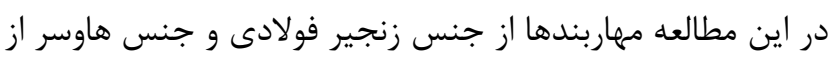

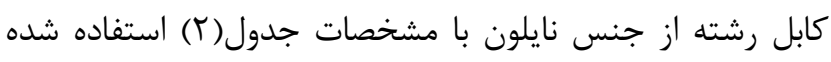

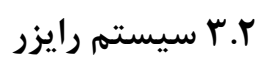

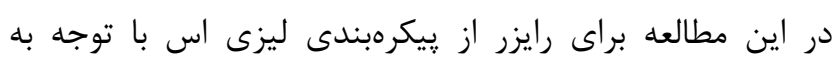

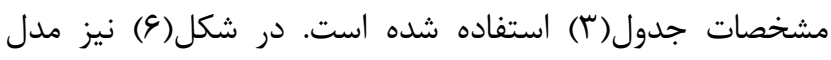

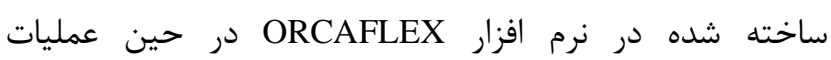
تخليه/باركيرى تانكر نشان داده شده است.

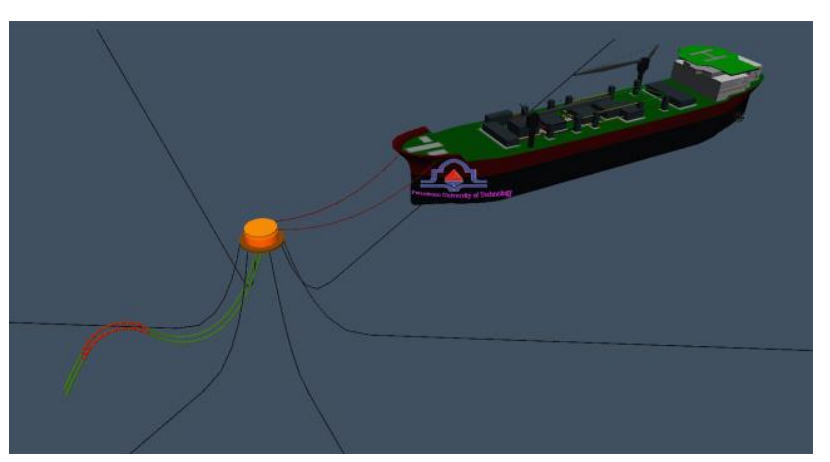

شكل و. مدل ساخته شده در نرم افزار ORCAFLEX 


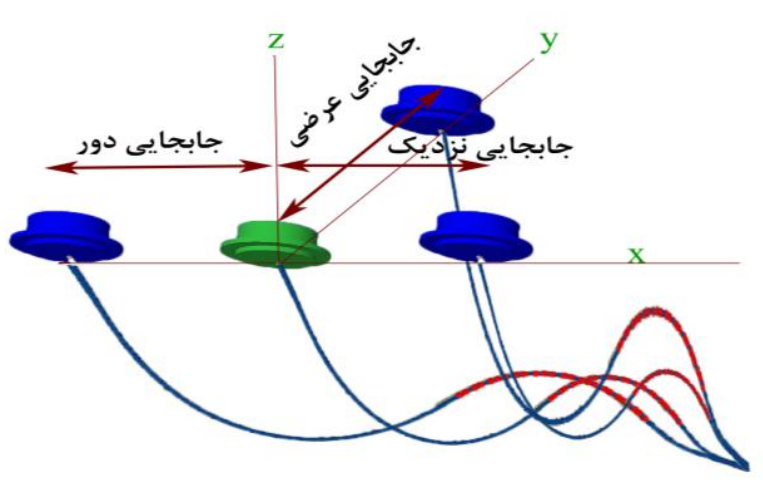

شكل ^. جهتهاى جابجايى ترمينال

در اين راستا يارامترهاى مورد نظر مطابق جدول(9) تا • بـ درصد تغيير از مقدار مرجع لحاظ شده اند تا روند تغيير در جابجايى

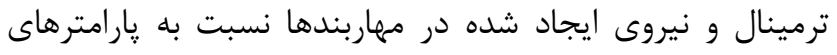

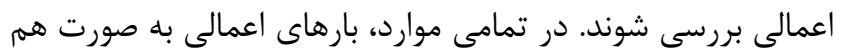

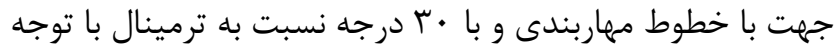
به شكل V مىباشد. همجنين بارهاى موج، جريان و باد به صورت

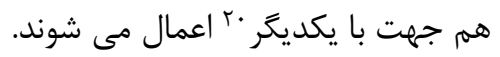

جدول \&. تغييرات اعمالى در ارامتر هاى عملياتى

\begin{tabular}{|c|c|c|c|}
\hline $\begin{array}{r}+30 \% \\
\times \text { ميزان مرجع }\end{array}$ & مرجع & 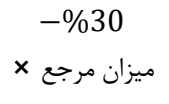 & يار امترها \\
\hline GT.IF & Fr.A & Tr.fe & عمق آب[m] \\
\hline$\cdot . r M Y$ &. .11. & $\cdot .1 \% 9$ & وزن زنجير ] \\
\hline १.Vब & V.D & $\Delta . T_{\Delta}$ & [s] يريود موج] \\
\hline$\cdot .91$ & $\cdot . v$. &. .49. & 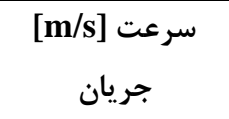 \\
\hline$v 1.19$ & 9.99 & FT.YA & [m] طول هاوسر \\
\hline
\end{tabular}

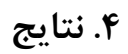

در اين مقاله، ترمينال نفتى CALM تحت پِارامترهاى عملياتى مختلف همجون عمق آب، وزن زنجير، سرعت جريان، دوره تناوب

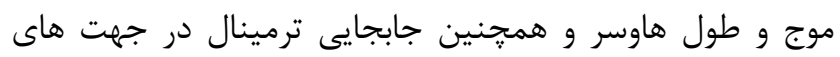
مختلف و ميزان تاثير حضور تانكر تحت مطالعه قرار ترفته است. در

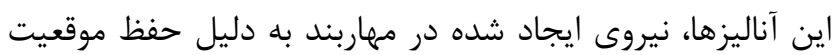

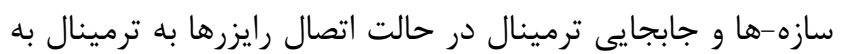

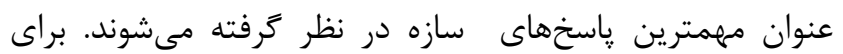

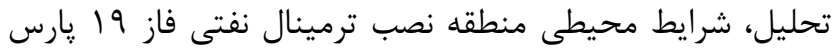

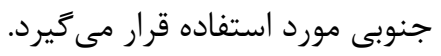

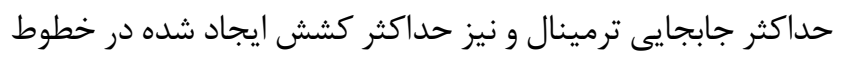
مهاربندى برحسب تغييرات در عمق آب، در نمودار شكل(ج) آرائه
جدول ه. شرايط محيطى اعمال شده

\begin{tabular}{|c|c|c|c|}
\hline$r .9$ & $\mathrm{H}_{\mathrm{S}}[\mathrm{m}]$ & \multirow{3}{*}{ جانسواٍ } & \multirow{3}{*}{ موج } \\
\hline V.D & $\mathrm{T}_{\mathrm{p}}[\mathrm{s}]$ & & \\
\hline 1. 1. & $\gamma$ & & \\
\hline$\cdot . V$ & 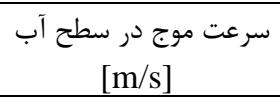 & \multirow{2}{*}{ مثلثى } & \multirow{2}{*}{ جريان } \\
\hline$\cdot$ & سرعت موج در بستر دريا & & \\
\hline & $r \varepsilon \mathrm{m} / \mathrm{s}$ & ثابت & باد \\
\hline
\end{tabular}

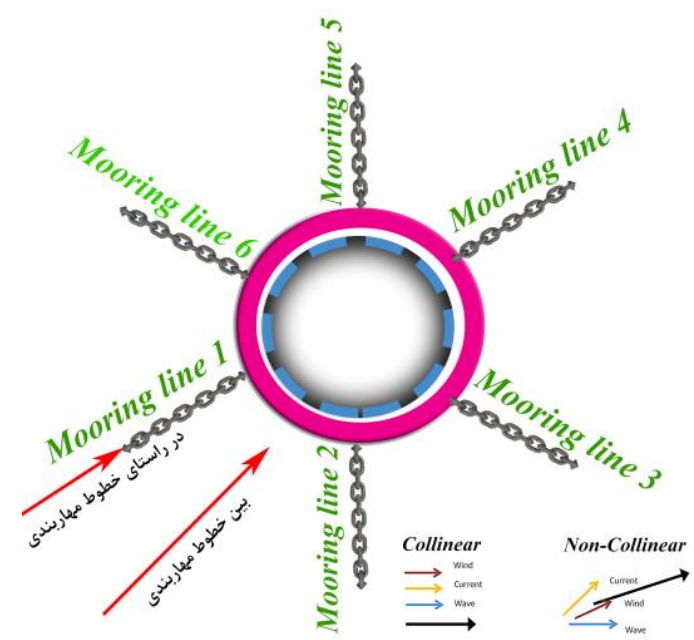

شكل V . نحوه جيدمان خطوط مههاربندى و راستاى بارَذارى

با توجه به روابط ارائه شده در قسمت ז، مىتوان نشان داد كه پاسخ

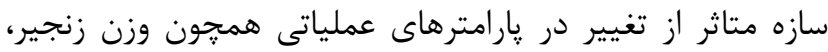

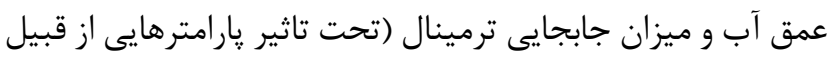

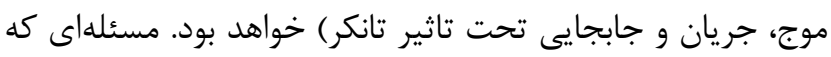

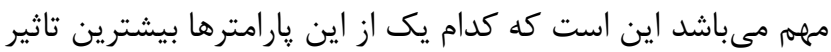

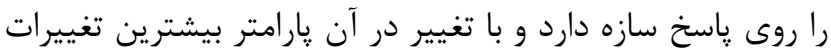

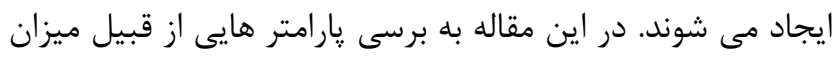

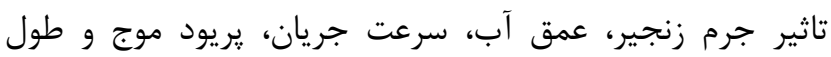

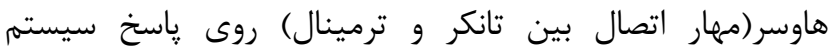
مهاربندى و تاثير جهت جابجايى ترمينال و ميزان تاثير حضور تانكر

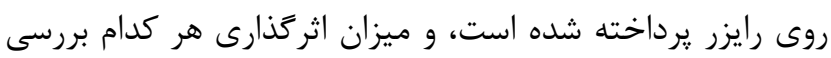
خواهد شد. براى بررسى رفتار رايزر، جابجايى ترمينال در سه جهت نزديك، دور،

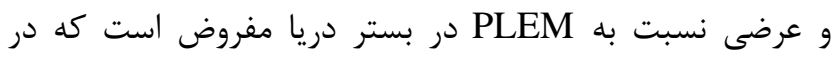
شكل(N) اين جابجايى ها به صورت شماتيك نشان داده شده است. 
شكل •l. ميزان تاثير يريود موج بر ياسخ سازه

طول هاوسر يا همان كابل اتصال بين تانكر و ترمينال، از ديخر متغيرهاى موثر بر קاسخ ديناميكى سازه است. در اين مطالعه،

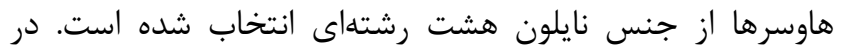
شكل(1) تاثير طول هاوسر بر حداكثر جابجايى ترمينال و نيز

حداكثر كشش ايجاد شده در خطوط مهاربندى نشان داده است.

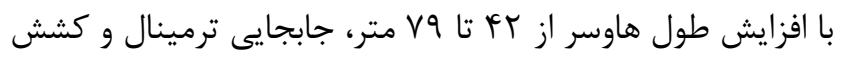

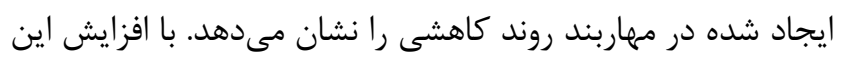

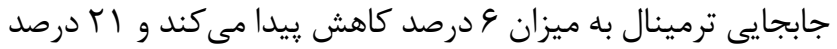

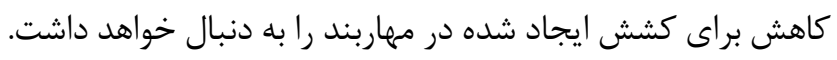

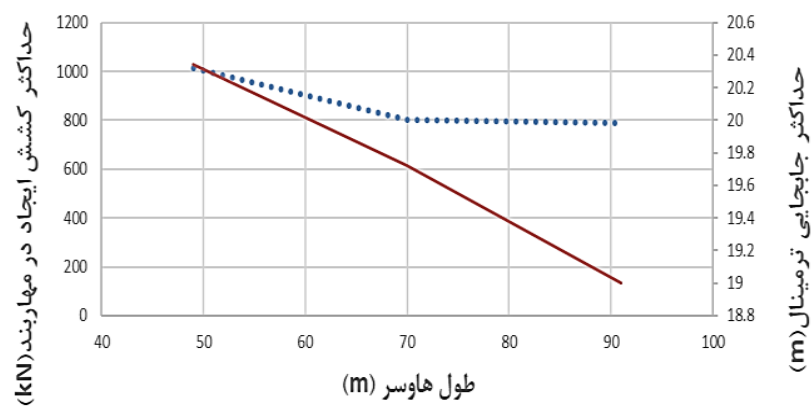

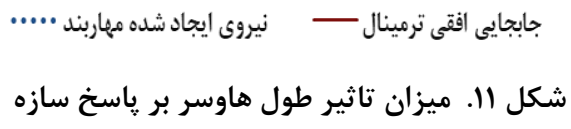

با متغير قرار دادن سرعت جريان به عنوان بار اعمالى، تغييرات در

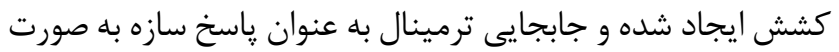
شكل(Y) (I) نتيجه مىشود.

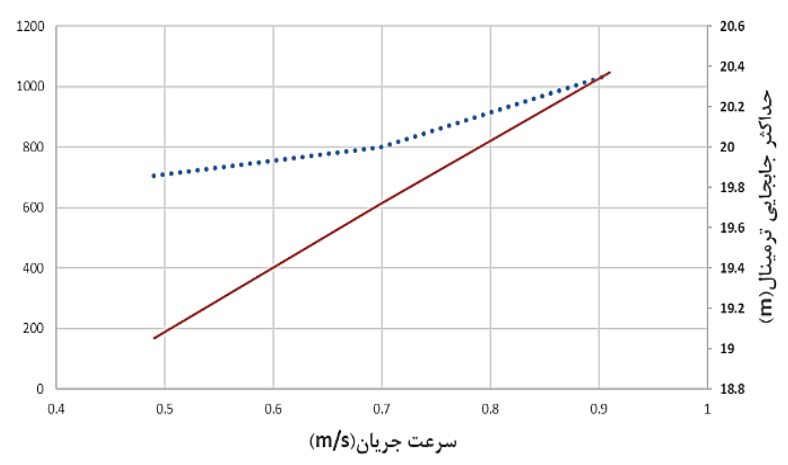

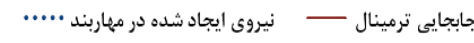

شكل rا ـ ميزان تاثير سرعت جريان بر هاسخ سازه تردين

با توجه به شكل rا انتيجه مىشود كه با افزايش سرعت جريان، كشش در مهاربند و جابجايى در ترمينال روند صعودى از خود نشان

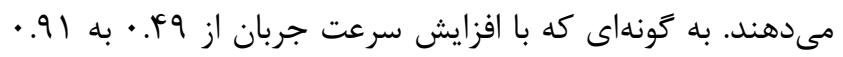

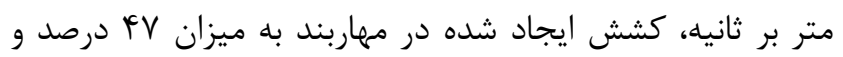
براى جابجايى ترمينال ميزان V درصد افزايش را نشان مى دهد.
شده است. همانطور كه در اين شكل مشخص است، رفتار نمودار را

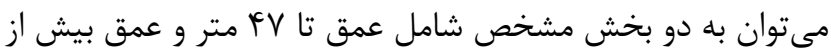

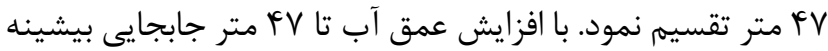

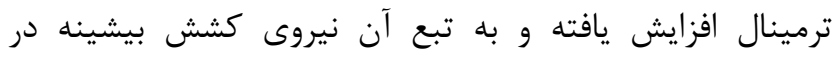

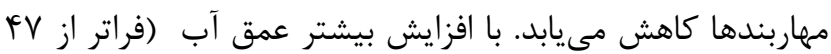
متر) با توجه به شكل( () طول بيشترى از مهاربند از بستر دريا جدا

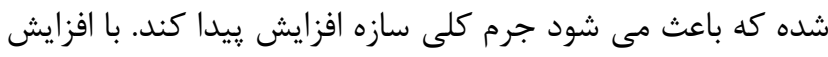

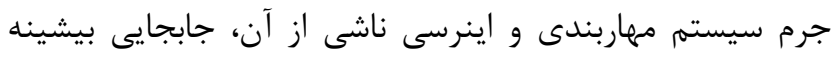
ترمينال كاهش يافته و روند كاهش نيروى كششى داخل مهاربند با بانيا شدت كمترى كاهش مى يابد كه اين ناشى از افزايش نيروى بويانسى نئ نافئ ناشى از طول زنجير مهاربندى خواهد كاهن بود.

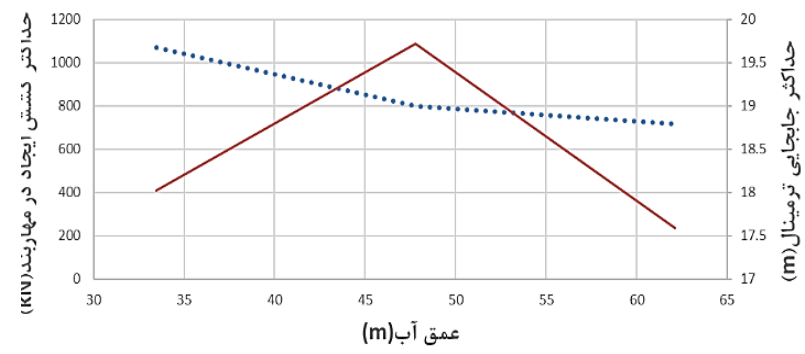

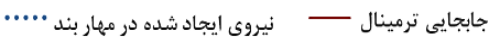

شكل 9. تاثير يارامتر عمق آب روى ياسخ سازه

در ادامه دوره تناوب موج به عنوان متغير براى بررسى حساسيت

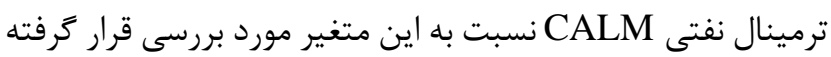
است. همانطور كه در شكل( • () مشخص است، جابجايى ترمينال و

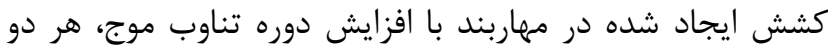

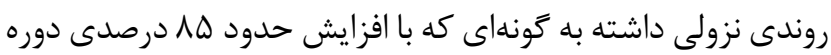

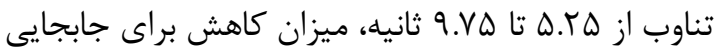

ترمينال مقدار r| درصد و براى كشش ايجاد شده درمهاربند به ميزان بس درصد تغييرات كاهشى را نشان مىدهد.

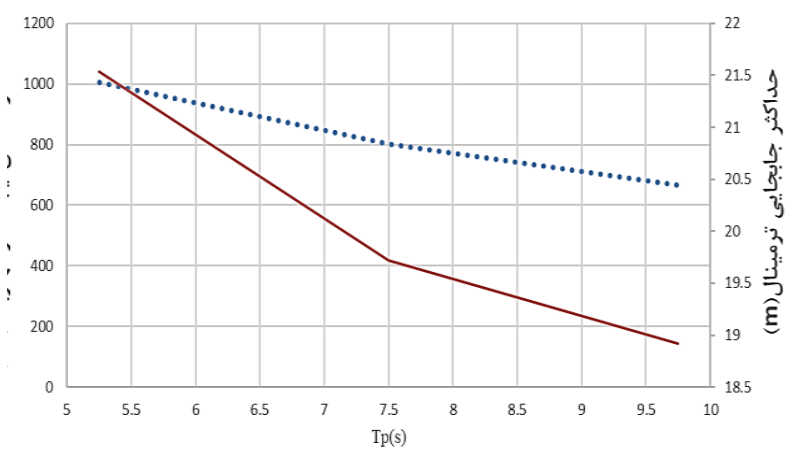

جابجاييى ترمينال - - ـ - نيروى ايجاد شده در مهاريند ..... 
نزديك، دور و عرضى مورد بررسى قرار مى گيرد و تاثيرى كه اين جابجايىها مىتوانند روى ياسخ ديناميكى رايزر داشته باشند مورد

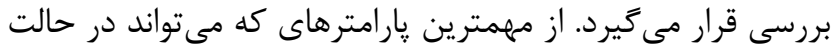

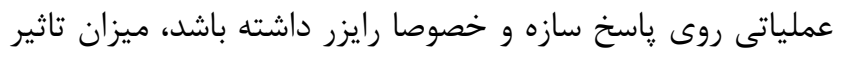
حضور تانكر است. در اين حالت براى بررسى رايزر از معيار كنترل

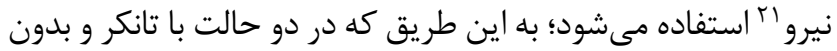
تانكر ترمينال مىتواند تحت شرايط محيطى اعمالى جابجا شود. اما

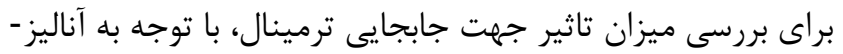

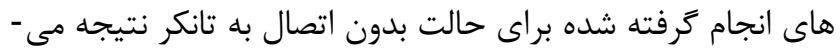

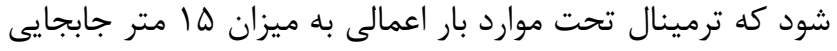

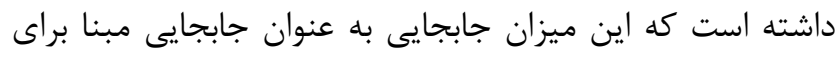

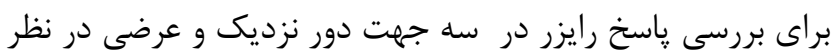

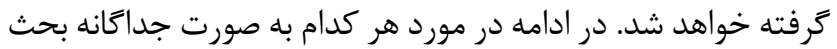
خواهد شد. درصورتيكه ميزان تاثير حضور تانكر براى بررسى ياسخ سازه مورد

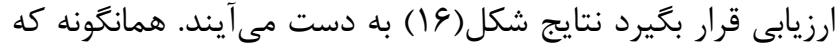

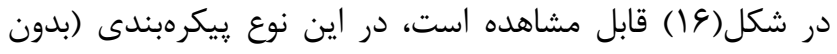

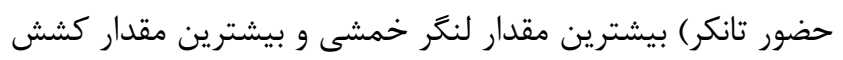

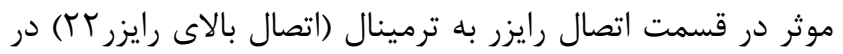
حالت ديناميكى بوجود مى حآيد. با اتصال تانكر به ترمينال، ميزان

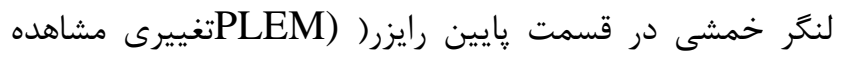

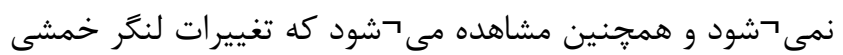

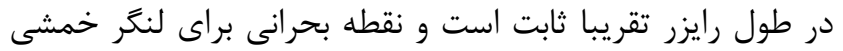
هنغام عمليات باركيرى همان نقطه اتصال بالاى رايزر مى حباشد.

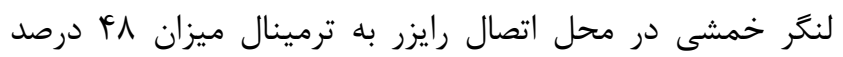

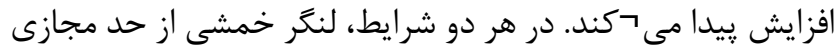

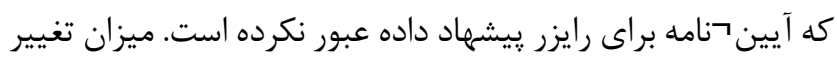

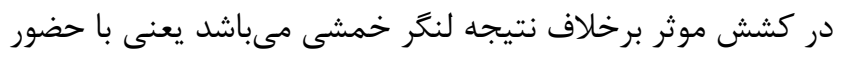

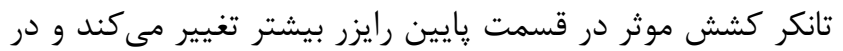
قسمت اتصال بالاى رايزر، كشش موثر تقريبا تغييرى ندارد. ميزان

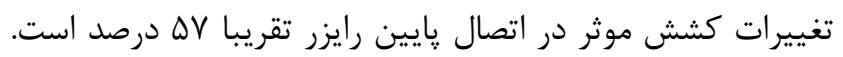

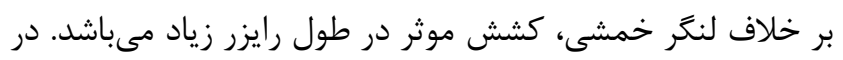

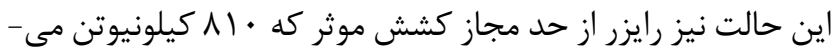
باشد تجاوز نكرده است.
با متغير قرار دادن جرم زنجير مهاربند، تغييرات در پاسخ سازه با توجه به شكل (rا () قابل مشاهده است.

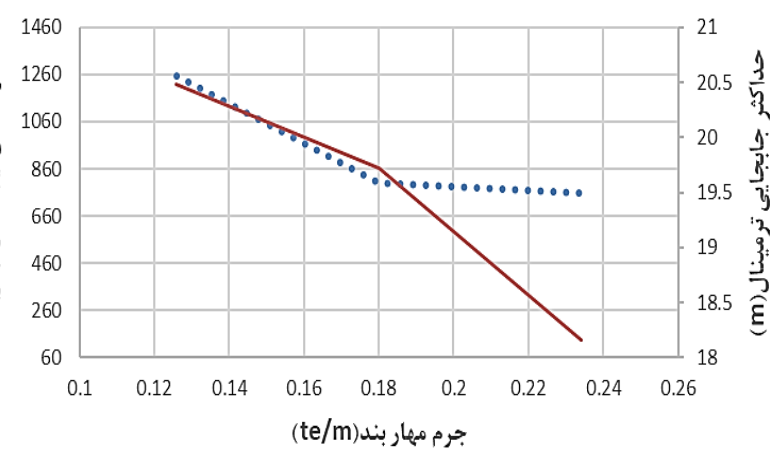

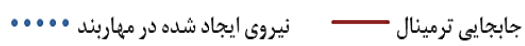

شكل سا. ميزان تاثير جرم مهاربند بر ياسخ سازه

با افزايش جرم مهاربند ميزان جابجايى ترمينال و كشش ايجاد شده

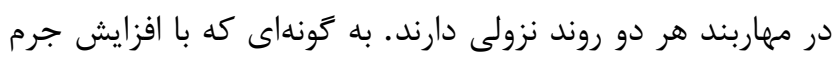

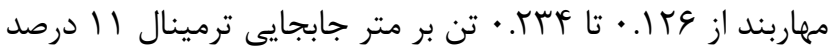

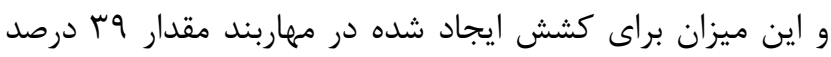

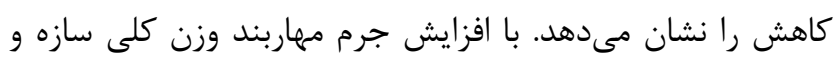
اينرسى آن افزايش ويدا مى كند در نتيجه جابجايى سازه كاهش و ونان به تبع آن نيروى ايجاد شده در مهاربندها نيز كاهش بيدا بيدا مى كند.

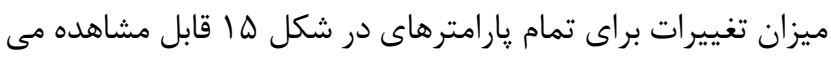
باشد

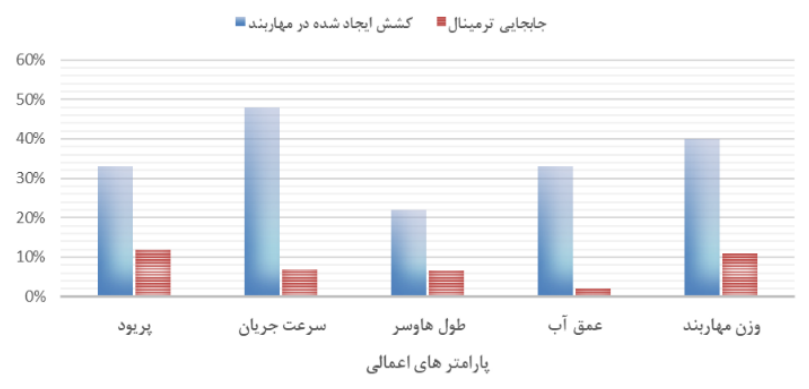

شكل If. ميزان تغييرات ياسخ سازه تحت پارامترها طراحى

رايزرها به عنوان مهمترين اجزاى ترمينال نفتى نيز با دو متغير شامل جابجايى ترمينال در جهتهاى مختلف و حضور و عدم حضور تانكر مورد بررسى قرار مى 

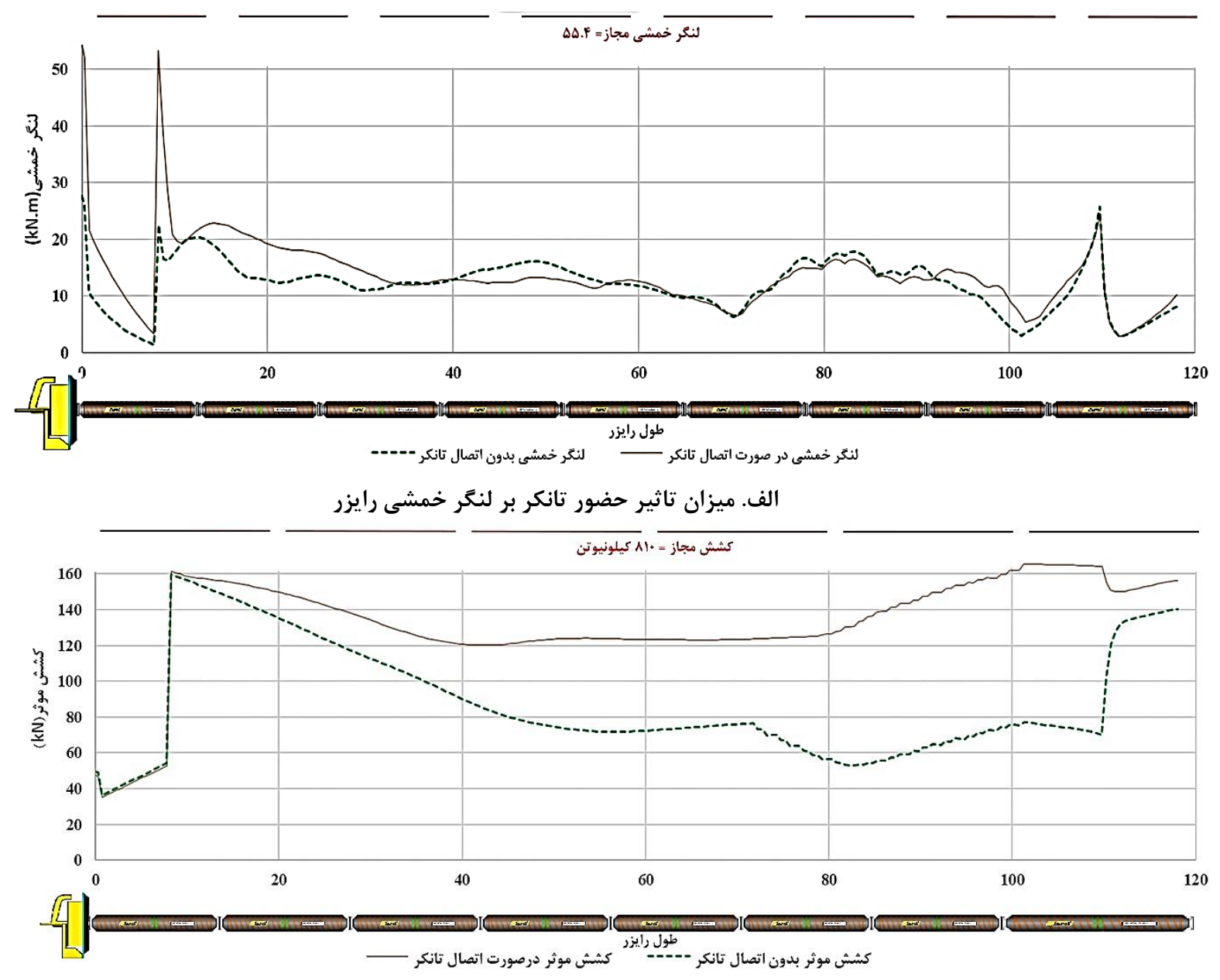

ب. ميزان تاثير حضور تانكر بر كشش موثر رايزر

شكله1 ـ ميزان تاثير حضور تانكر بر ياسخ ديناميكى سازه

دور كمترين مقدار را دارا مىباشد. همانكونه كه مشاهده مىشود

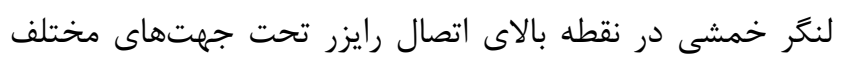

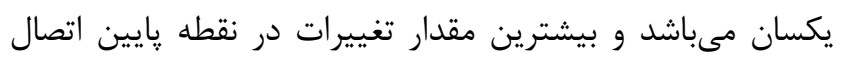

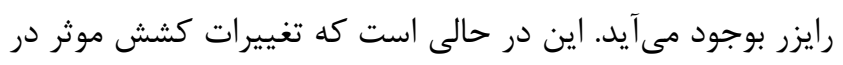

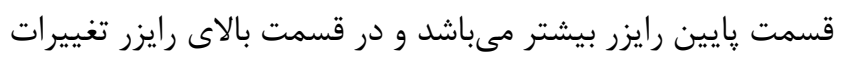

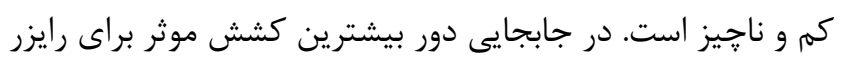

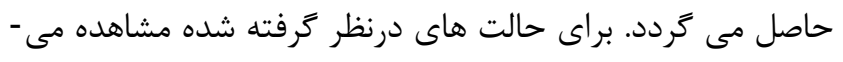

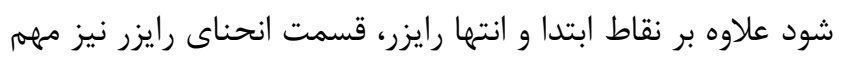

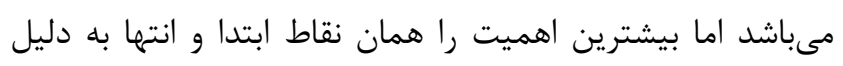
تغييرات بيشتر نيرو را دارند.
در شكل(ه) ميزان تاثير جابجايى ترمينال در جهتهاى مختلف

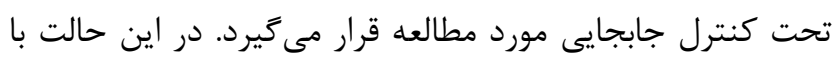

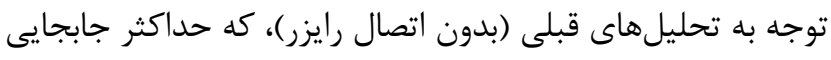

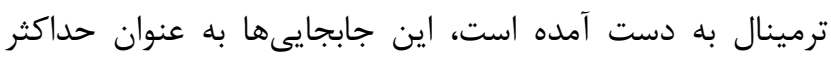
جايجايى كه ترمينال مىتواند تحت شرايط محيطى موجود داشت دابها

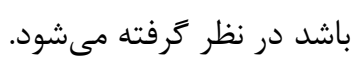

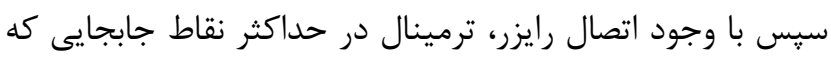

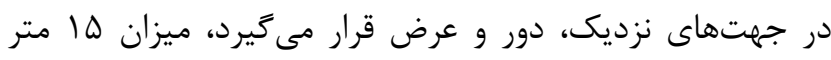

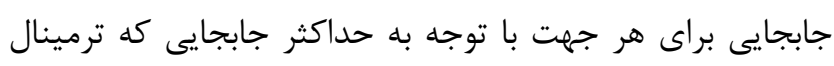

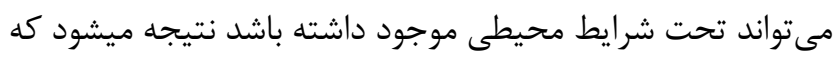

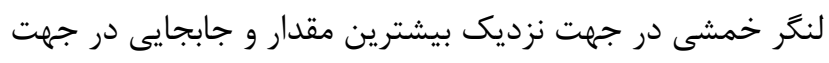




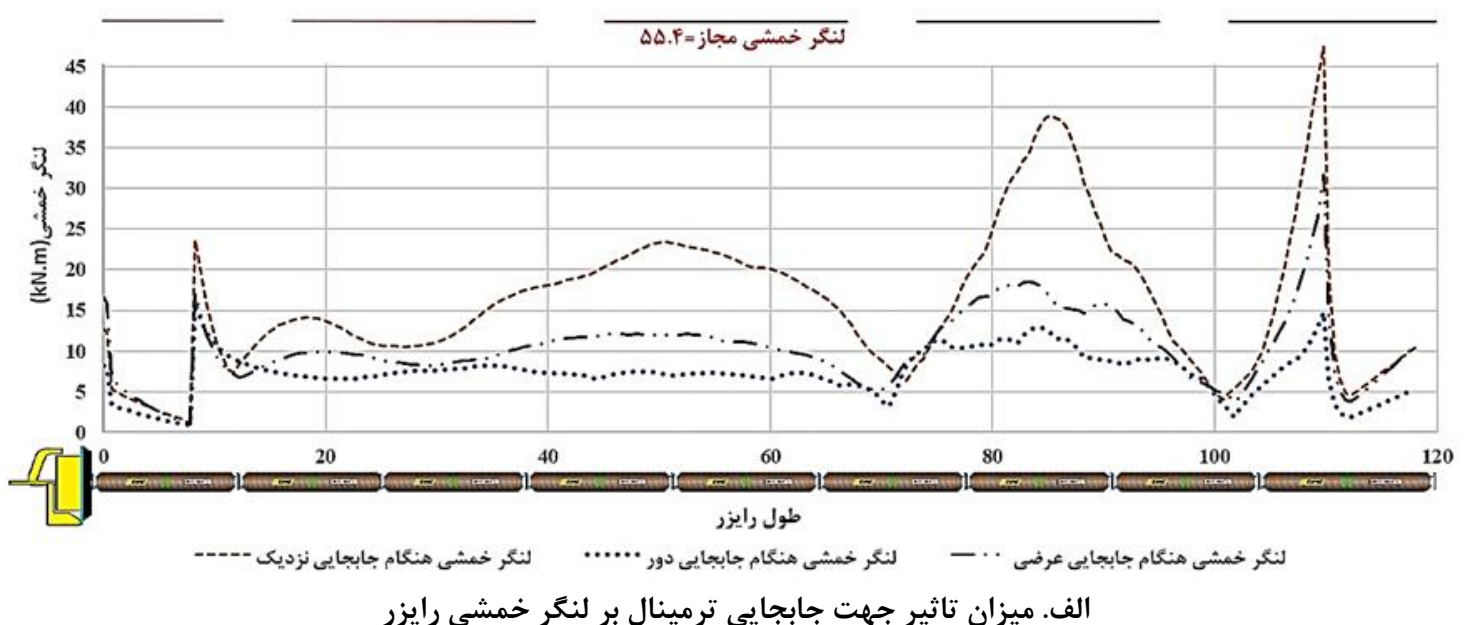

الف. ميزان تاثير جهت جابجايى ترمينال بر لنغَر خمشى رايزر

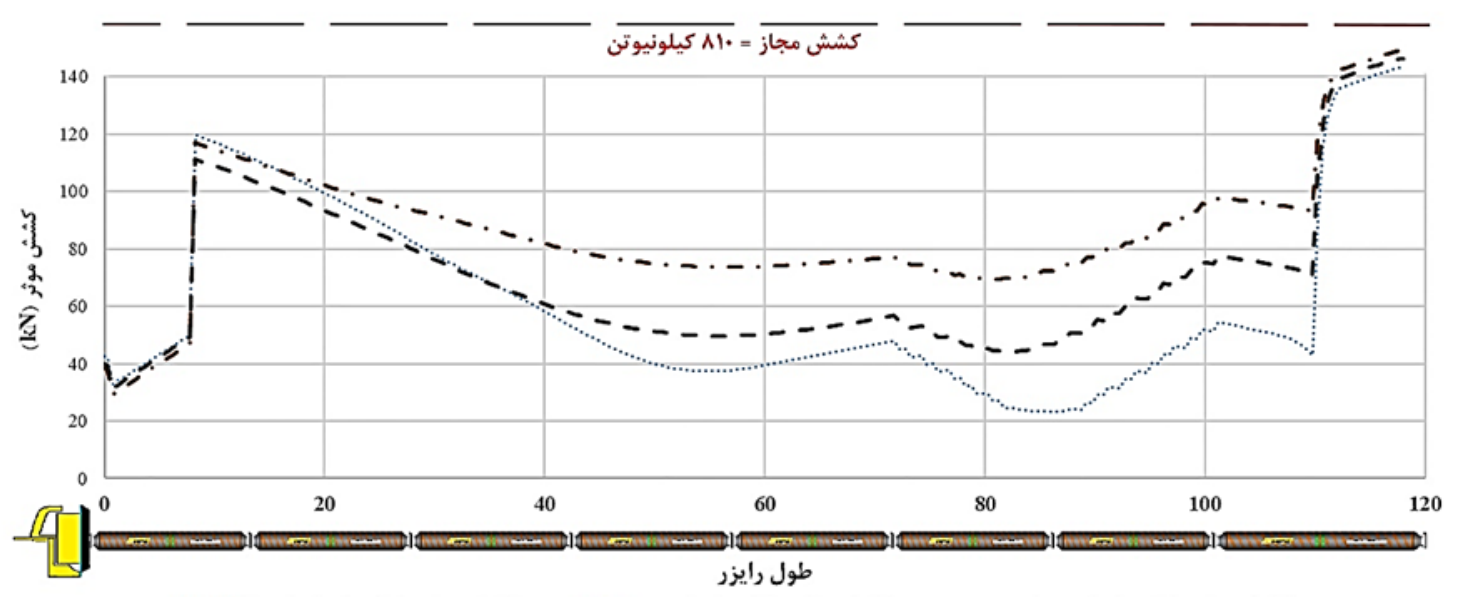

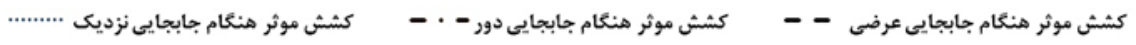

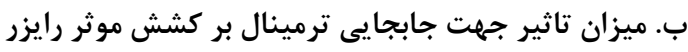

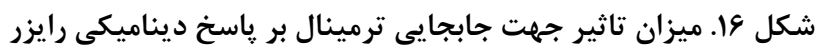

و كشش موثر در قسمت پايين رايزر بيشترين تغييرات

رخ مىدهد. همجنين مشاهده مىشود كه در صورت

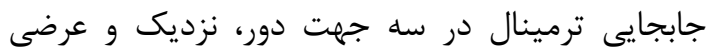

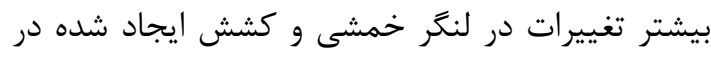

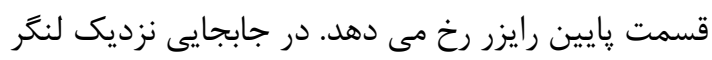
خمشى و در جابجايى دور كشش ايجاد شده در مهاربند بيشترين تغيرات ايجاد مى شود.

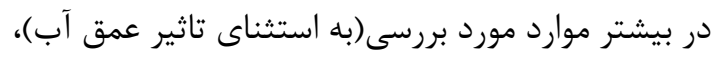
نيروى ايجاد شده در مهاربند و جابجايى ترمينال رابطه برده

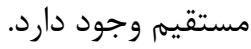

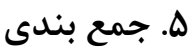

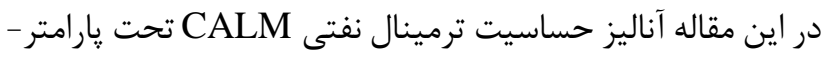
هاى مختلف با شرايط محيطى منطقه نصب ترمينال نفتى فاز 19

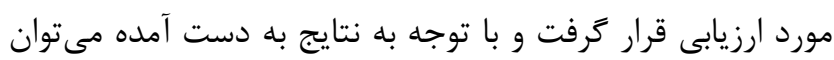
نتيجه كرفت كه:

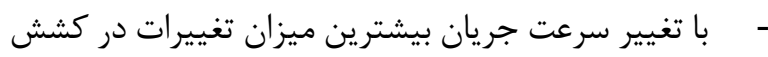

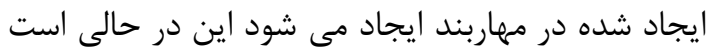

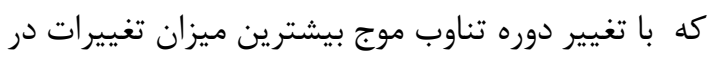
جابجايى ترمينال مشاهده مى شود. براى ساير يارامترها در شكل(9) اين ميزان تغييرات آورده شده است.

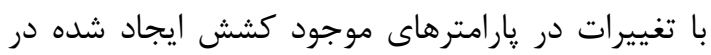

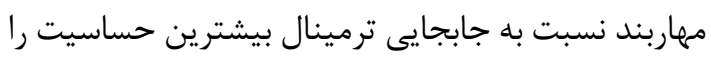

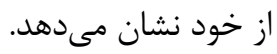
براى اين نوع پِيكرهبندى رايزر مىتوان نشان دان داد

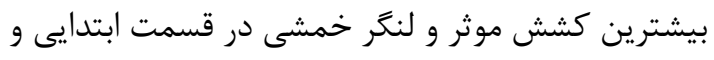

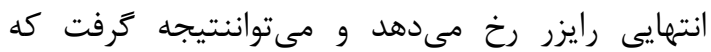
درصورت اتصال تانكر، لنكر خمشى در قسمت بالاى رايزر 
[7] X. Qi, Y. Chen, Q. Yuan, G. Xu, and K. Huang, "Calm Buoy and Fluid Transfer System Study," in The 27th International Ocean and Polar Engineering Conference, 2017.

[8] J. J. Ziccardi and H. J. Robins, "Selection of Hose Systems for SPM Tanker Terminals," in Offshore Technology Conference, 1970.

[9] C. Eiken, "Pre-commissioning hose operations on the Valemon field in the North sea." University of Stavanger, Norway, 2013.

[10] C. V. Amaechi, F. Wang, X. Hou, and J. Ye, "Strength of submarine hoses in Chineselantern configuration from hydrodynamic loads on CALM buoy," Ocean Eng., vol. 171, pp. 429-442, 2019.

[11] A. R. Cruces Girón, F. N. Corrêa, B. P. Jacob, and S. F. Senra, "An Integrated Methodology for the Design of Mooring Systems and Risers of Floating Production Platforms," in International Conference on Offshore Mechanics and Arctic Engineering, 2012, vol. 44885, pp. 539-549.

[12] A. R. C. Girón, F. N. Corrêa, A. O. V. Hernández, and B. P. Jacob, "An integrated methodology for the design of mooring systems and risers," Mar. Struct., vol. 39, pp. 395-423, 2014.

[13] A. R. Cruces Girón, F. N. Corrêa, and B. P. Jacob, "Evaluation of Safe and Failure Zones of Risers and Mooring Lines of Floating Production Systems," in International Conference on Offshore Mechanics and Arctic Engineering, 2013, vol. 55317, p. V001T01A024.

[14] “AQWA User Manual." [Online]. Available: https://www.sharcnet.ca/Software/Ansys/14.0/ en-us/help/wb_aqwa/wb_aqwa.html.

[15] T. Edition, "API RP 2SK Design and Analysis of Stationkeeping Systems for Floating Structures," no. October 2005. 2014.

[16] Orcaflex, OrcaFlex Manual version 9.7a,2015. section 1;3;4;6;7, 2015.

[17] American Petroleum Institute, "Recommended Practice for Flexible Pipe (API Recommended Practice 17B Third Edition)," no. March. 2002.
1- Catenary Anchor Leg Mooring

2- Single Anchor Leg Mooring

3- Skirt

4- Chinese Lantern

5- Hose

6- Ziccardi

7- Lazy S

8- Free hanging

9- Flow angle

10- Hawser

11- Weathervaning

12- Chain

13- Wire

14- Fiber Rope

15- Under-Water Hose

16- Vulcanization

17- Bonded

18- Minimum Breaking Tension

19- Minimum Bending Radius

20- Collinear

21- Load Control

22- Hang-off

V V

[1] A. M. Salancy and R. G. Bea, "Offshore single point mooring systems for import of hazardous liquid cargoes," California Univ., Berkeley, CA (United States). Dept. of Naval Architecture ..., 1994.

[2] G. Rutkowski, "A comparison between conventional buoy mooring CBM, single point mooring SPM and single anchor loading SAL systems considering the Hydro-meteorological condition limits for safe ship's operation offshore," TransNav Int. J. Mar. Navig. Saf. Sea Transp., vol. 13, no. 1, 2019.

[3] "Marine Hoses | YOKOHAMA RUBBER Co., Ltd. MULTIPLE BUSINESS." [Online]. Available: $\quad$ https://www.yyokohama.com/global/product/mb/marinehoses/. [Accessed: 26-Nov-2019].

[4] K. Wang, G.-K. Er, and V. P. Iu, "Nonlinear dynamical analysis of moored floating structures," Int. J. Non. Linear. Mech., vol. 98, pp. 189-197, 2018.

[5] E. Esmailzadeh and A. Goodarzi, "Stability analysis of a CALM floating offshore structure," Int. J. Non. Linear. Mech., vol. 36, no. 6, pp. 917-926, 2001.

[6] A. Pecher, A. Foglia, and J. P. Kofoed, "Comparison and sensitivity investigations of a CALM and SALM type mooring system for wave energy converters," J. Mar. Sci. Eng., vol. 2, no. 1, pp. 93-122, 2014. 